\title{
ABSTRAK \\ SELF MANAGEMENT PADA PASIEN DIABETES MELLITUS DENGAN LUKA BERSIH
}

\author{
Marina Kristin L ${ }^{1}$, Abdurrahman², Silvina Era Artalia Apriani ${ }^{3}$, Theresia Welly ${ }^{4}$, Tri Ratna Rahayu ${ }^{5}$ \\ Program Studi Ilmu Keperawatan, Institut Teknologi Kesehatan dan Sains Wiyata Husada Samarinda ${ }^{1,2,3,4,5}$ \\ *Korespondensi: marina@itkeswhs.ac.id, abdurrahman@itkeswhs.ac.id
}

\begin{abstract}
Diabetes Melitus (DM) adalah penyakit metabolik kronis yang disebabkan oleh ketidakmampuan tubuh untuk memproduksi hormon insulin sesuai kebutuhan atau karena penggunaan yang tidak efektif dari insulin atau keduanya Self-management dapat mendorong pasien menggunakan sumber daya yang ada untuk mengelola gejala yang dialaminya terutama pada pasien dengan penyakit kronis. Pelaksana melakukan kegiatan pemeriksaan kadar glukosa dan penyuluhan mengenai self management pada pasien diabetes melitus dengan luka basah. Hasil kegiatan menunjukkan bahwa Self Management Pada Pasien Diabetes Mellitus memiliki peran yang cukup signifikan dalam meningkatkan kualitas hidup Diabetes Mellitus. Kesimpulan self management pada pasien diabetes melitus menjadi strategi yang tepat untuk memberdayakan masyarakat dalam rangka meningkatkan kesiapan pasien untuk melakukan perawatan mandiri pada anggota keluarga yang menderita Diabetes Mellitus dan self care behavior pada pasien Diabetes Mellitus.
\end{abstract}

Kata Kunci: self management, Diabetes Mellitus, Luka Bersih

\section{PENDAHULUAN}

Diabetes Melitus (DM) adalah penyakit metabolik kronis yang disebabkan oleh ketidakmampuan tubuh untuk memproduksi hormon insulin sesuai kebutuhan atau karena penggunaan yang tidak efektif dari insulin atau keduanya. Gangguan tersebut dapat disebabkan oleh sekresi hormon insulin tidak adekuat atau fungsi insulin terganggu (Resistensi insulin). Secara garis besar DM dikelompokkan menjadi 2 tipe, yaitu: DM tergantung pada insulin (DM tipe1) dan DM tidak tergantung pada insulin (DM tipe-2) (Stevens, 2002).

Di dunia pada tahun 2010 diperkirakan ada sekitar 59 juta orang yang menderita DM dan pada tahun 2030 diperkirakan akan meningkat 2,5 kali lipat sehingga mencapai 145 juta penderita. Di Indonesia sendiri, World Health Organization (WHO) memperkirakan jumlah penderita diabetes mellitus di Indonesia meningkat tiga kali lipat dari data tahun 2000 dimana jumlah penderita mencapai 8,4 juta, maka dalam 10 tahun tepatnya tahun 2010 mencapai 21,3 juta orang (PERKENI, 2006). Upaya untuk mengurangi resiko tersebut, maka diperlukan suatu program penatalaksanaan diabetes secara mandiri bagi para diabetisi ini (Sutandi, 2012).

Pengendalian DM akan lebih efektif bila diprioritaskan pada pencegahan dini melalui upaya perawatan mandiri pasien di keluarga. Program Self-management dapat mendorong pasien menggunakan sumber daya yang ada untuk mengelola gejala yang dialaminya terutama pada pasien dengan penyakit kronis (Warsi et al, 2004). Diabetes Self-Management Education (DSME) merupakan proses pendidikan kesehatan bagi individu atau keluarga dalam mengelola penyakit diabetes. DSME menggunakan metode pedoman, konseling, dan intervensi perilaku untuk meningkatkan pengetahuan mengenai diabetes dan meningkatkan ketrampilan individu dan keluarga dalam mengelola penyakit DM (Jack et al., 2004). 


\begin{abstract}
Tujuan dari kegiatan Kelompok Pendamping Diabetes Self Management Education (KP-DSME Keluarga) adalah meningkatkan pengetahuan, keterampilan, dan kemampuan keluarga dalam melaksanakan perawatan mandiri pada anggota keluarga yang menderita DM, meningkatkan self care behavior pada pasien DM sehingga status kesehatan dan kualitas hidup masyarakat khususnya pada penderita DM meningkat.
\end{abstract}

\section{METODE PELAKSANAAN}

Adapun metode pelaksanaan dan alur pelaksanaan pengabdian masyarakat ini yaitu :

1. ITKes Wiyata Husada Samarinda bekerja sama dengan Puskesmas Juanda kota Samarinda untuk pelaksanaan pemeriksaan glukosa dan penyuluhan

2. Melakukan sosialisasi dan memaparkan rencana pengabdian masyarakat di RT 32 kelurahan air hitam, akan dilakukan kegiatan yaitu melaksanakan pemeriksaan kadar glukosa dan penyuluhan mengenai dampak glukosa yang tinggi.

3. Pelaksanaan pengabdian masyarakat berupa kegiatan pemeriksaan glukosa dan penyuluhan

4. Pelaksana menyiapkan alat dan perlengkapan yang digunakan saat kegiatan pemeriksaan dan penyuluhan.

5. pelaksana melakukan kegiatan pemeriksaan kadar glukosa dan penyuluhan mengenai self management pada pasien diabetes melitus dengan luka basah

6. Melakukan evaluasi

\section{HASIL KEGIATAN}

Pelaksanaan kegiatan PKM Kelompok Pendamping Diabetes Self Management Education Berbasis Keluarga (KP-DSME KELUARGA) telah dilaksanakan melalui tahapan sosialisasi, peningkatan kompetensi, pelaksanaan kegiatan, serta monitoring dan evaluasi. Melalui metode sosialisasi memberikan hasil bahwa pasien dan keluarga memahami, mempunyai pola fikir dan mempunyai komitmen dalam meningkatkan derajat kesehatan khususnya keluarga diabetisi. Salah satu langkah untuk mencapai suatu kesuksesan sebuah program ialah melalui sosialisasi.

Pada metode peningkatan kompetensi, sebelumnya dilakukan pengumpulan informasi kepada pasien dan keluarga kesehatan dengan menggunakan kuesioner tentang segala hal yang berkaitan dengan perawatan mandiri pasien DM di rumah seperti bagaimana perencanaan pola makan dan diet yang tepat, cara memonitoring kadar gula darah secara berkala, cara olahraga dan latihan yang tepat pada penderita DM, dll dilanjutkan dengan pemberian materi dan diakhiri dengan evaluasi tentang pengetahuan dan ketrampilan kader setelah pemberian materi. Hasil pengumpulan informasi awal tentang pengetahuan dan kemampuan kader berkaitan dengan perawatan mandiri pasien DM di rumah menunjukkan hampir seluruh pasien dan keluarga kesehatan belum memahami tentang perawatan mandiri pasien DM di rumah. Setelah dilaksanakan proses pendampingan oleh TIM PKM maka kemampuan kader kesehatan tentang perawatan mandiri pasien DM di rumah mengalami peningkatan yang signifikan.

Pada pelaksanaan kegiatan PKM ini dilaksanakan dengan bekerjasama melibatkan pusat pelayanan kesehatan terdekat dengan masyarakat yaitu Puskesmas Juanda, puskesmas sangat mendukung keberhasilan kegiatan PKM ini. DepKes RI (2004), Puskesmas adalah unit pelaksana teknis Dinas Kesehatan Kabupaten atau Kota yang bertanggung jawab menyelenggarakan pembangunan kesehatan di suatu wilayah kesehatan. Puskesmas merupakan pusat pengembangan kesehatan masyarakat dalam membina peran serta masyarakat juga memberikan pelayanan secara menyeluruh dan terpadu kepada masyarakat. Puskesmas mempunyai wewenang dan tanggung awab atas pemeliharaan kesehatan masyarakat dalam 
wilayah kerjanya. Pelayanan kesehatan yang diberikan puskesmas adalah pelayanan kesehatan menyeluruh yang meliputi pelayanan: kuratif (pengobatan), preventif (upaya pencegahan), promotif (peningkatan kesehatan), dan rehabilitatif (pemulihan kesehatan).

Selain itu, dalam pelaksanaan kegiatan ini juga dilakukan pendampingan pada pasien dan keluarga dalam melakukan perawatan mandiri pasien DM di rumah. Pendampingan ini terdiri dari kegiatan perencanaan pola makan dan diet yang tepat, cara memonitoring kadar gula darah secara berkala, cara olahraga dan latihan yang tepat pada penderita DM, cara mengurangi resiko seperti luka DM yang sukar sembuh, managemen stress, dan pengobatan yang teratur, penyampaian materi pelatihan tentang masalah pasien dengan DM, mendemonstrasikan cara perencanaan pola makan dan diet yang tepat, cara memonitoring kadar gula darah secara berkala, cara olahraga dan latihan yang tepat pada penderita DM atau senam DM, cara mengurangi resiko seperti luka DM yang sukar sembuh, serta cara managemen stress. Seluruh kegiatan ini dilakukan dengan metode pelatihan, role play, pemberian pendidikan kesehatan, dan penyuluhan.

Pemberian pendidikan kesehatan dan penyuluhan pada hakikatnya merupakan suatu kegiatan untuk menyampaikan pesan kepada masyarakat, kelompok, atau individu dengan harapan kelompok tersebut mendapatkan pengetahuan tentang kesehatn yang lebih baik. Hal ini seirama dengan pendapat Notoadmodjo (2005) yang menyatakan bahwa informasi akan berpengaruh terhadap pengetahuan seseorang. Pada kegiatan pendidikan kesehatan dan penyuluhan ini TIM PKM menggunakan berbagai media diantaranya power point, leaflet, dan lembar balik. Pada metode monitoring dan evaluasi dilaksanakan 1 bulan setelah dilakukan pemberian informasi dengan cara seluruh kader kesehatan dan pembina wilayah puskesmas dikumpulkan untuk dilakukan monev terhadap pelaksanaan kegiatan selama KP-DSME berlangsung. Monitoring dan evaluasi merupakan sebuah proses yang berkesinambungan meliputi pengumpulan data, proses dan pemilihan informasi mengenai implementasi proyek, progress yang dicapai pada proyek tersebut sampai kepada dampak dan efek dari adanya proyek tersebut (Ojha, 1998

Berdasarkan hasil monitoring evaluasi juga didapatkan peningkatan yang signifikan pada kualitas hidup diabetisi. Hasil pengontrolan kadar gula darah didapatkan data bahwa sebagian besar kadar gula darah diabetisi terkontrol dengan baik. Hal ini menunjukkan bahwa PKM KP-DSME memiliki peran yang cukup signifikan dalam meningkatkan kualitas hidup diabetisi. Keunggulan Program Pengabdian Masyarakat Kelompok Pendamping Diabetes Self Management Education Berbasis Keluarga (KPDSME Keluarga) yaitu menjadi strategi yang efektif dan terintegrasi, berbasis masyarakat melalui kerjasama lintas program dan lintas sektor untuk meningkatkan kualitas hidup masyarakat yang menderita Diabetes Mellitus. Pada Pelaksanaan kegiatan pengabdian ini tidak dialami kesulitan yang signifikan karena keluarga dan Puskesmas mampu bekerjasama dengan sangat baik.

\section{KESIMPULAN}

Pengabdian masyarakat Kelompok Pendamping Diabetes Self Management Education Berbasis Keluarga (KP-DSME Keluarga) dapat disimpulkan bahwa terbentuknya forum diskusi keluarga yang berfokus pada DM dibawah binaan Puskesmas Juanda, meningkatnya kemampuan dan ketrampilan keluarga terkait perawatan mandiri pasien DM dari $20 \%$ menjadi $85 \%$, meningkatnya kesiapan anggota keluarga untuk melakukan perawatan mandiri pada anggota keluarga yang menderita DM dan self care behavior pada pasien DM dari 30\% menjadi $80 \%$. KP-DSME berbasis Keluarga menjadi strategi yang tepat untuk memberdayakan masyarakat dalam rangka meningkatkan kesiapan anggota 
keluarga untuk melakukan perawatan mandiri pada anggota keluarga yang menderita DM dan self care behavior pada pasien DM. Rekomendasi untuk kegiatan PKM selanjutnya adalah mengembangakan KPDSME berbasis Keluarga di seluruh RT 32 Kelurahan Air Hitam dan tidak hanya berfokus pada DM tetapi juga pada penyakit kronis tidak menular lainnya.

\section{REFERENSI}

American Diabetes Association. 2011. Diabetes

Statistics: 2011 National diabetes fact sheet.http://www.diabetes.org/diabetesbas ics/diabetes-statistics/. November 10th, 2011.

Stevens J, Ahn K, Juhaeri, Houston D, Steffan L, Couper D. 2002. Dietary Fiber Intake and Glycemic Index and Incidence of Diabetes in AfricanAmerican and White Adults: the ARIC Study.Diabetes Care 25:1715-21

Cushway B. 2001. Manejemen Sumber Daya Manusia. Jakarta: Gunung Agung.

Dahmiri, Sakta. 2014. Pengaruh Pelatihan terhadap Kinerja Pegawai Dinas Pendidikan Kabupaten Sarolangun. Mankeu, Vol. No. 3 No.1 2014:374- 463.

Departemen Kesehatan RI. 2004. Pedoman Penyelenggaraan Puskesmas di Era Desentralisasi. Jakarta: Balai Pustaka

Muktiali M. 2009. Penyusunan Instrumen Monitoring Dan Evaluasi Manfaat Program Pembangunan Di Kota Semarang. Riptek, Vol.3, No.2, Tahun 2009, Hal.: $11 \pm 20$

Nainggolan N. 2013. Dampak Sosialisasi Program Keluarga Berencana Dalam
Pengambilan Keputusan Keluarga Untuk Menggunakan Kontrasepsi Di Kecamatan Samarinda Ulu Kota Samarinda. eJournal llmu Komunikasi, 2013, 1 (2): 389-399 ISSN 0000-0000, ejournal.ilkom.fisipunmul.ac.id

Notoadmodjo. 2005., Metodologi Penelitian Kesehatan Edisi Revisi. Jakarta: PT Rineka Cipta

Ojha D. 1998. Impact Monitoring Approaches and Indicators. GTZ: Escborn

PERKENI. 2006. Konsensus pengelolaan DM tipe 2 di Indonesia. Jakarta: PB PERKENI

Rahayu E, Kamaluddin R, Sumarwati M. 2014. Pengaruh Program Diabetes Self Management Education Berbasis Keluarga Terhadap Kualitas Hidup Penderita Diabetes Melitus Tipe II Di Wilayah Puskesmas II Baturraden. Jurnal Keperawatan Soedirman (The Soedirman Journal of Nursing), Volume 9, No.3, Juli 2014

Sutandi, A. 2012. Diabetes Self Management Education (DSME) sebagai metode alternative dalam perawatan mandiri pasien diabetes mellitus di dalam keluarga. EJournal Widya, vol 29, no 321

Warsi, et al. 2004. A systemic review and methodological critique of the literature: original invertigation self management education programs in chroni deseases. Intern med, vol 164, Aug 9/23

Yuanita, Wantiyah, Susanto. 2014. Pengaruh diabetes self management education terhadap resiko terjadinya ulkus diabetik pada pasien rawat jalan dengan DM type II di RSD Jember E-journal Kesehatan, Vol 2, No 1, Januari, 2014 